\title{
YAZILI, GÖRSEL VE SOSYAL MEDYADA GIDA İLE İLGİLİ BİLGİ KİRLILIIGGIINİN HALKIN GIDA TERCİHİ ÜZERİNE ETKILERİ*
}

\author{
Kübra Sağlam ${ }^{2 * *}$, Tuncay Gümüş ${ }^{3}$ \\ ${ }^{2}$ İstanbul Gelişim Üniversitesi, İstanbul Gelişim Meslek Yüksekokulu, Gıda İşleme Bölümü, Gıda Teknolojisi \\ Program1, İstanbul, Türkiye \\ ${ }^{3}$ Namık Kemal Üniversitesi, Ziraat Fakültesi, Gıda Mühendisliği Bölümü, Tekirdağ, Türkiye \\ Geliş/Received: 28.10.2018; Kabul/Accepted: 09.02.2019; Online bask1/Published online: 20.02.2019
}

Sağlam, K., Gümüş, T. (2019). Yazılı, görsel ve sosyal medyada gıda ile ilgili bilgi kirliliğinin halkın gida tercihi üzerine etkileri. GIDA (2019) 44 (1): 153-162 doi: 10.15237/gida.GD18108

Sağlam, K., Gümüs, T. (2019). The effects of food-related misconception in printed, visual and social media on the consumer. GIDA (2019) 44 (1): 153-162 doi: 10.15237/gida.GD18108

\section{ÖZ}

Teknolojinin gelişmesi, sanayileşme, eğitim düzeyinin, ekonomik ve sosyal refahın artması insanların gidalara ve sağlıklı beslenmeye olan ilgisini arttırmıştır. Ancak doğru ve yeterli bilgi sahibi olmayan kişilerce yapılan yanlıss açıklamalar tüketicide kafa karışıklı̆̆ına neden olabilmektedir. Bu çalışma, beslenme ile ilgili halkın bilinç düzeyini ölçmek, günümüzün en büyük sorunlarından biri haline gelen bilgi kirliğinin ortadan kaldırlması ve doğru bilginin doğru uzman kaynağından elde edilebilmesi konusunda halkın bilinçlendirilmesi amacıyla yapılmışıtı. Bu amaçla, sosyal medya üzerinden toplumun farklı kesimlerinden, farklı bölge ve eğitim düzeyinden toplam 616 kişi ile anket yapılmış ve sonuçlar SPSS.20 programı ile değerlendirilmiştir. Araştırma sonuçlarına göre, tüketici doğru bilgi kaynağını bilemediğinden özellikle medyadaki bilgi kirliliğinin, onların beslenme konusunda çok daha büyük yanlışlar yapmasına yol açtı̆̆ tespit edilmiştir. Yazılı, görsel ve sosyal medyada gıda ile ilgili yorumların alanında uzman olan kişiler tarafindan yapılması dolayısıyla halkın doğru bilgi kaynaklarına yönlendirilmesi çok önemlidir.

Anahtar kelimeler: Gıda Bilinci, Bilgi Kirliliği, Sosyal Medya

\section{THE EFFECTS OF FOOD-RELATED MISCONCEPTION IN PRINTED, VISUAL AND SOCIAL MEDIA ON THE CONSUMER}

\begin{abstract}
The development of technology, industrialization, the increase of economic and social prosperity and the level of education, have increased the interest of people in food and healthy nutrition. However, misrepresentations made by the people who do not eligible and have sufficient information on the subject can cause more confusion in the consumer. This study was conducted in order to measure people's level of consciousness about the food and nutrition, to remove the misinformation that has become one of the biggest problems in nowadays and to make the public aware of the correct information from the right experts or the source. For this purpose, a total of 616 people from different parts of the society, different regions and education levels were surveyed via social media, and the results were evaluated with the SPSS.20 program. According to the results of the research, it has been determined that the misinformation in the media caused more confusion among the consumers who does not know the correct source of information. Therefore, it is important that the information about the food and nutrition in written, visual and social media should be given by the experts in the field, so that people may acquire correct information from those platforms.
\end{abstract}

Keywords: Food Consciousness, Information Pollution, Social Media

* Kübra Sağlam'ın Yüksek Lisans Tezinden Üretilmiştir

${ }^{* *}$ Yazışmalardan sorumlu yazar / Corresponding author;

$\square$ kubrasaglam1453@gmail.com, @ (+90) 2822504400,

且 $\quad(+90) 2822509930$ 


\section{GİRİ̧̧}

Medya, kültürün ulusal ve uluslararası düzeyde bireylere ulaştırılması noktasında önemli bir görev üstlenmektedir. Özellikle toplumsal hayatta bireylerin çeşitli sosyal ihtiyaçlarını gidermek için sıklıkla başvurdukları önemli bir kaynaktır (Kocadaş, 2006). Sosyal medya ise; yeni nesil web teknolojilerinin kullanıcıya getirdiği kolaylık ve iletişim hızı sayesinde eş zamanlı bilgi paylaşımının bireylerce takip edildiği dijital bir platformdur (Tezgüler, 2016). Sosyal medyanın gıda ile ilgili olarak gıda kaynaklı hastalık gözetimi için potansiyel olarak zengin bir veri kaynağ1 olduğu ve sosyal medyanın kasıtlı ve kasıtsız gıda kirliliğinin tespitini kolaylaştırabileceği yeni yolları oluşturabildiği bildirilmiştir (Newkirk ve ark. 2012).

Teknolojinin gelişmesi, sanayileşme, eğitim düzeyinin, ekonomik ve sosyal refahın artması insanların gidalara ve sağlıklı beslenmeye olan ilgisini arttırmıs, bilinçli beslenme günümüzde toplumun ilgisini çeker hale gelmiştir. Bu durum sosyal medyada gida ile ilgili açılama ve haber sayısını da arttırmıştır. Ancak doğru ve yeterli bilgi sahibi olmayan kişilerce yapılan yanlış açıklamalar tüketicide kafa karışıklığına neden olabilmektedir. Tüketici doğru bilgi kaynağını bilememekte dolayısıyla bilgi kirliliği oranı beraberinde artarak, tüketicinin beslenme konusunda daha büyük yanlışlar yapmasına yol açmaktadır.

Bilgi kirliliği, genelde, gidada var olan etkinin abartılarak yansitilması, gidada var olmayan fonksiyonların varmış gibi ifade edilmesi, gıdanın sağlıksız veya tehlikeli olduğunun bilimsel olmayan bir çerçevede ifadesi olarak gelişmektedir ve bu gelişimler, tüketicilerin kamu otoritelerine olan güvenlerinin sarsilması ve mevzubahis g1daları tüketmekten bir süreliğine veya tamamen vazgeçmeleri ile neticelenmektedir. (Sungur, 2014).

G1da ve beslenme konusunda tam anlamı ile günümüzde gerek sosyal medyada gerek basilı yayınlarda büyük bir bilgi kirliliği mevcuttur. İnsanlar ne yiyip ne yemeyeceği konusunda endişe etmesinin nedeni, konu üzerinde bilgisi olmayan ve medya tarafindan büyütülen kişilerin yanlışs yönlendirmesinden kaynaklanmaktadır. Yapılan alg1 araştırmalarına göre bu verilere inanışın temel nedenleri arasında yönlendirmeyi yapanların bir kısmının toplum tarafından güvenilir kabul edilen mesleklere (tup doktoru vb.) sahip olmasindan ileri gelmektedir. TV programlarında bu kişilerin artık aileden biri gibi kabul edilmesi de etkendir. Her insan kendi beslenme inanışlarına/ alışkanlıklarına devam etmekte özgürdür. Ancak kimse başkalarının beslenme tarzına bilimselliği kanıtlanmamış yönlendirmelerde bulunma hakkına sahip değildir. Bilgi farklı bir şeydir, bilimsel temellerle uyuşmak zorundadır. (Halkman, 2015).

Gıdaların üretim teknolojileri ve ürün özellikleri hakkında bilimsel-mesleki yetkinliğe sahip olmayan kişiler tarafindan popüler olmak, kitaplarının reklamını yapmak, satışını arttırmak ve muayenelerine gelen hasta sayisinin arttırmak amacıyla bilgi sahibi olmadığı halde herhangi bir bilimsel temele dayanmadan açılama yaptıkları görülmektedir. Bu asılsız, hiçbir bilimsel temeli olmayan ve etik kurallara uymayan açiklamalar, süt, ekmek, yumurta gibi temel gidalarla ilgili olarak bile yapılmakta, tüketicilerin kaygı düzeyini yükselterek, beslenmeleri konusunda hatalar yapmalarına yol açmaktadır. Beslenmede yapılan hatalar, sağlıkla ilgili geri dönüşsüz birçok tehlikeyi ortaya çıkarmaktadır. Tüm bu rahatsız edici durumların yanında bu kişilerin bazı gıda gruplarına karşı kuşkuların oluşmasına sebep olan yanlış ve gerçeklikten uzak açıklamalarının sorgulanmadan, işin gerçek uzmanlarına danışllmadan medya tarafından yüksek reyting beklentisiyle kamuoyuna aktarilmasıdır (Songül, 2015).

Medyada gıda konusundaki bilgi kirliliği; gereksiz ve yanlış bilgilerle "bilgi obezitesi" olan toplumun, bilimi temel alan "bilgi diyetine" ihtiyacı vardır. Günümüzde medya aracilığ ile istenilen bilgiye istenilen zamanda ulaşabilmekte "Kuşkusuz bilgiye bu kadar kolay ve hızlı bir şekilde ulaşmak zamanın verimli kullanılması açısından çok önemli bir rahatlıktır. Besleyici değeri yüzyıllardır bilinen gidalar hakkındaki yanlış bilgilendirmelerin, ülkemizde zaten yetersiz ve dengesiz beslenme alışkanlığı olan halkımızın 
daha fazla beslenme sorunlarılyla karşı karşıya kalmasına zemin hazırlamaktadır (Artık, 2014).

Kitleler, gıda güvenliği ve halk sağlığını ilgilendiren konuları çoğunlukla yazılı ve görsel basın aracillğı ile takip ederler (Avşar ve ark. 2006). Sosyal medya da gıda ile ilgili yoğunlaşan bilgi kirliliği sebebiyle güvenilir bilgi için daha seçici yaklaşımlarda bulunmak gerekmektedir. Sosyal medyada gida alanında yetkinliği olmayan bazı kişilerce yapılan bilimsel olmayan açıklamalar neticesinde toplum araştırma yöntemlerini kullanmamakta ve toplumun çoğu sosyal medyada yapilan her beslenme tavsiyesine uyar hale gelmiştir. Bu durum halkın sağlı̆ı̆nı tehlikeye atmakta ve yüzlerce 'Doğru Bilinen Yanlışlar' kavramını karşımıza çıkarmıştır.

Karaali'nin (2012) gıda riskleri konusunda yapılan bilgilendirmelere duyulan güven hususuna dair yapmış olduğu anket çalışmasına göre; Türkiye'de bilim insanlarına duyulan güvenin $\% 53$, hekimlere $\% 41$, gida üreticilerine $\% 20$, tüketici örgütlerine \% 16, yazılı veya görsel bilgi veren medyaya güvenin $\% 14$, sivil toplum kuruluşlarına $\% 13$, yasal otoritelere $\% 13$ olduğu saptanmıştır.

Sosyal medyada yer alan beslenme alışkanlıkları ve g1da maddeleri ile ilgili haberlerin bireylerin beslenme alışkanlıklarında değişiklik yapmaları ile ilişkisini saptamaktır. Günümüzde her yaş, her sosyokültürel ve her eğitim düzeyinden çok sayıda insanın sosyal medya kullanicisıdır. Sosyal medyanın pazarlamadaki rolü yadsinamaz olduğundan, çalışmanın sosyal medya üzerindeki beslenme alıskanlıkları ile ilgili haberlere ilgisi, bu haberlere karşı duyduğu güven/güvensizlik, bu haberler neticesinde beslenme alışkanlıklarında değişiklik yapma isteği gibi konuların çalışılması insan sağlığı açısından da önem arz etmektedir. Bu çalışma beslenme ile ilgili halkın bilinç oranını ölçmek, günümüzün en büyük sorunlarından biri haline gelen bilgi kirliğinin ortadan kaldırılması ve doğru bilginin doğru uzman kaynağından elde edilebilmesi konusunda tüketicileri bilinçlendirme amaciyla yapılmıştır. Sosyal medya kullanıciları arasından değişik yaşam standartlarına sahip olan 616 kişilik tesadüfi olarak seçilen grubun, beslenme, çeşitli besin maddeleri ve önemi konularında ne kadar bilgi sahibi olduklarının anlaşılması ve medyanın gıda tüketim tercihlerinde ne kadar etkili olduğu belirlenmeye çalışılmıştır.

\section{MATERYAL VE YÖNTEM}

Araştırmada ölçeği geliştirilirken yapılan hesaplamalar sonucunda anketin sosyal medya kullanıcıları arasından farklı yaş gruplarındaki 600 kişiye uygulanması hedeflenmiştir. Türkiye'de “Internet World State" verilerine göre; 2015 nüfus sayıs1 77.695.904 kişi, 2014 Aralık tarihinde internet kullanıcısı sayıs1 46.282 .850 kişidir. İnternet kullananlar nüfusun $\% 60 ' 1$ kadardir. Facebook kullanan kişi sayısı ise ortalama 32 milyon dolayındadır (Anonim 2015). Araştırmanın evreni Türkiye'deki 18-24, 25-24 ve $55+$ yaş aralığında ki sosyal medya kullanıcıları olarak tespit edilmiştir. Örneklem büyüklüğünün hesaplanmasına dair çeşitli formüller verilmekle birlikte bu araştırmada örneklem sayısının belirlenmesinde Yamane (2001) tarafindan belirtilen örneklem formülü kullanılmıştır. Örneklem formülü aşağıdaki gibidir.

$n=\frac{N \cdot z^{2} \cdot p \cdot q}{N \cdot d^{2}+z^{2} \cdot p \cdot q}$

$\mathrm{n}=$ Örnek çap1 (Araştırma için uygulama yapılacak kissi sayısı)

$\mathrm{N}=$ Evren (yığındaki birim sayısı)

$\mathrm{z}=$ Standart normal dağılım tablo değeri (Araştırmada istenilen güvenilirlik düzeyi \%95 gibi)

$\mathrm{d}=$ Duyarlılık (Araştırma için kabul edilebilir hata pay1-0,05)

$\mathrm{p}=$ Araştırmaya konu olan özellikleri taşıan bireylerin oranı

$\mathrm{q}=$ Araştırmaya konu olan özellikleri taşımayan bireylerin oran $1(\mathrm{p}+\mathrm{q}=1)$

Araştırmaya 616 kişi katılmış ve kitlesel hedefe ulaşılmıştır. Kişiler Tesadüfü örnekleme yöntemi ile seçilmiştir.

Çalışmada bireylerin beslenme alışkanlıklarını değiştirme ve sosyal medyadaki ilgili haberlerin ilişkisini saptayabilmek amaciyla anket yöntemi kullanılmıştır. $\mathrm{Bu}$ araştırmada genel tarama 
modeli kullanılmış olup, genel tarama modelleri çok sayida elemandan oluşan bir evrende, evren hakkında genel bir yargiya varmak amaciyla evrenin tümü ya da ondan alınacak bir grup üzerinde yapilan tarama düzenlemeleridir. (Karasar, 2000). Araştırma materyalini toplama online anket formları kullanılmışır. Anket formunda tüketicilere gıda bilinci ile ilgili bilgileri beş değişkenle (Kesinlikle Katılıyorum, Katıliyorum, Kararsizım, Katılmiyorum, Kesinlikle Katılmıyorum) değerlendirmeleri istenmiştir. Yapılan anket uygulaması çerçevesinde elde edilen veriler; faktör analizi, Varyans Analizi (ANOVA) ve T Testine tabi tutulmuştur. Analizler SPSS Statistics 20.0 paket programında gerçekleştirilmiştir. Ayrıca verilerin faktörleşmeleri faktör analizi ile incelenmiştir.

\section{BULGULAR VE TARTIŞMA}

Ankete katılan tüketici profili çizelge 1'de verilmiştir. Field (2009)'in yaptığ1 yeterlilik ölçütü değerlendirmesine göre sonuç 0.8-0.9 arasinda tespit edilmiş olup istatistiki olarak güvenilirlik anlamında 'çok iyi' grubunda kabul edilmektedir. Yapmış olduğumuz anket çalışmasında ise $\mathrm{KMO}$ ve Bartlett's Test tablosu incelendiğinde $\mathrm{KMO}$ örneklem yeterliliğinin 0.8-0.9 arasında tespit edildiğinden (0.847) uygun olduğu belirlenmiş ve böylelikle ilk olarak faktör analizinin anketimize uygunluğu tespit edilip ispatlanmıstır. Uygun olan anket çalışması için faktör analizi yapılarak 13 faktör belirlenmiştir. Bu faktörler; (Ambalaj), Gıda Katkı Maddesi (Katkı), Gıdanın Tavsiye edilmesinden Etkilenme (Tavsiye), Sağlık ve Gıda (Sağlık), Organik Pazarlara Güven (Organik Pazarlar), Medyada Açıklama Yapan Kişilerin Mesleği (Kimlik, meslek), Medyada Açıklama Yapan Kişilerin Ünlü Olması (Ün), Gıdaları Satın Alırken Dikkat Edilmesi Gerekenler (Satın Alma), Doğal Gidalar (Doğal), Yasak Olan Gidalar (Yasak), Hayvansal Gidalar (Hayvansal), Gıdaların Tazeliğinin Belirlenmesi (Tazelik) ve Gidaların Tercihinde Reklamin Etkisi (Reklam)'dır. (Çizelge 1)

G1da ambalajlarının kalitesini gösteren üç önemli unsur ambalajin koruyuculuğu, pazarlama unsuru ve tüketiciyi bilgilendirmektir. Tüketicilerin çoğunluğunun gida ambalajlarında son kullanma tarihini kontrol etme noktasında daha bilinçli olduğu görülmektedir. Gıdalara katkı maddeleri katılmasinın doğruluğu üretici ve özellikle tüketicileri ikiye bölen konulardan biri olmaktadır.

Sosyal medyada her meslek grubunun yaptığ1 açıklamaların ve yayınların kafa karışıklığı yaratabildiği bilinmektedir. Sonuçlar genel olarak tüketicinin katk1 maddelerine ve hazır ürünlere kesinlikle güvenmediğini ve özellikle son yillarda tartışma konusu olan sütlerde katkı maddesi olduğunu düşünenlerin sayısının hiç de azımsanmayacak oranda olduğu belirlenmiştir. Bu sonuçlar katkı maddeleri ile ilgili bilgi kirliliğinin varlığını göstermektedir. Sosyal medyada bazı meslek gruplarınca gida ile ilgili yapilan açıklamalar doğrultusunda tüketicinin tutumunun incelendiği 3. Faktör olan tavsiye faktörü altı soru ile belirlenmiştir. 3. Faktör olan tavsiye faktöründe tüketicinin uzmanlık alanını sorgulamaksızın, beslenme noktasinda belirli mesleklerden toplumun etkilendiği ya da baz1 açıklamalar sonucunda kararsız kalarak kafa karışıklğ̆1 yaşadığ1 tespit edilmiştir. En önemlisi sosyal medyanın beslenme tercihleri üzerinde büyük rol oynadığı yön verebilen bir unsur olduğu görülmüştür.

Sosyal medya da bilimsel bir veriye dayanmayan bazı beslenme tutumlarının sağlık üzerine etkisi ile ilgili yapılan açıklamaların tüketiciye etkisi doğrultusunda 4. faktörde, Besin grubu olarak bile aynı kategoride olmayan gidalar hakkında kıyaslama yapilması doğru bir yaklaşım olmadığı düşünülmektedir. Süt teknolojisi ve bitkisel yağ teknolojisi birbirinden farklı alanlar olmakla birlikte gıda kimyası bakımından incelendiğinde de zaten benzerlik göstermemektedir. Organik pazarlar ile ilgili yapilan haber ve reklamların etkisinin ölçüldüğü 5. faktörde verilen cevaplar incelendiğinde ve özellikle kararsız kitlenin fazla olmasını da göz önünde bulundurduğumuzda organik pazar kavramı hakkında tüketici de kafa karışıklı̆̆ı olduğu tespit edilmiştir. 
Çizelge 1: Demografik veriler

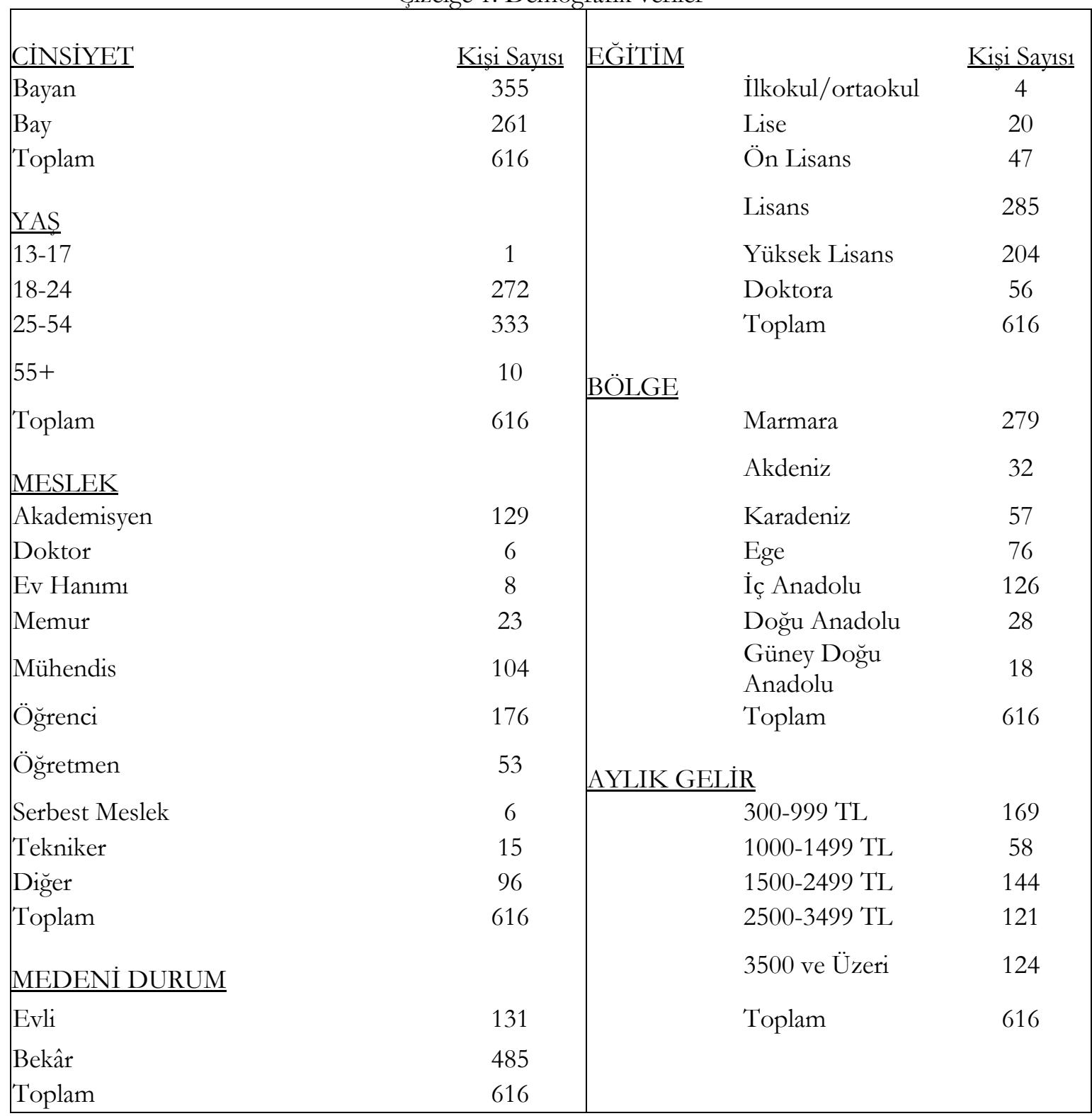

Meslek durumunun irdelendiği 6. faktörün sonuçlarına göre 3 değişkene de verilen $\% 80$ civarında ki olumlu cevaplar göstermektedir ki tüketici gerek TV, gerek internet üzerinden besin ve beslenme ile ilgili açıklamaları dinlerken, okurken bilgilendirme yapan kişinin mesleğine ve kimliğine dikkat etmekte ve Gıda Mühendislerini daha çok sosyal medyada görmek istemektedir. Sosyal medyada toplumda gerek mesleği gerekse günlük yaşamı ile ün kazanmış, son yıllarda kısa sürede ciddi kilo verip ilginç diyet listelerini sosyal medyada paylaşan kişilerden etkilenme durumunun incelendiği 7. Faktörde Diyet kitab1 olarak piyasaya sürülen kişiye özel bir liste oluşturmadan tüm insanları aynı kefeye koyup besin tavsiyeleri veren kitaplara karşı tüketicinin ilgisi olmadığı ve daha bilinçli olduğu görülmektedir. Bunlara ilave olarak, promosyon ürünler tüketici için sadece bir tercih meselesi olduğu görülmekte, alışverişte ciddi anlamda satın almayı etkilememektedir. Doğallık kavramı ile ilgili son soruda ise maden suyu ve soda 
karşılaştırması yapılmış, çoğu tüketici aynı olmadığının bilincindeyken, beşte birlik bu kitlenin kararsiz olmasi az da olsa bu konuda da kafa karışıklığı olduğunu göstermektedir. Sosyal medya da baz1 meslek gruplarinca bilimsel bir veriye dayandırılmadan gida hakkında yapilan açıklamaların tüketici üzerindeki etkisinin incelendiği 10.faktörde tüketicinin en yüksek paydalarına kesinlikle ile başlayan yargılarda rastlanması da tüketicinin bu konuda keskin değerler ile birbirinden ayrıldığını göstermektedir. Hayvansal gidalar ile ilgili sosyal medyada yapılan çeşitli tüketim tavsiyelerinin tüketici üzerine etkisi incelendiğinde tüketicinin çiğ yumurtaya karşı daha duyarlı olduğu görülmektedir. Tazelik faktörünün tüketici üzerine olan etkisi iki değissken ile incelenmiştir. En çok yapilan hatalardan bir tanesi olan küflü gıdaların küflü kısmını atıp gerisini tüketme durumu ile ilgili soruya ise tüketicilerin \%36. 9'u kesinlikle katılmamaktadır. Bu konuda tüketicinin günümüzde daha bilinçli olduğu söylenebilir. Reklamların tüketicinin gida tercihi üzerinde ki etkisinin olmadığ tespit edilmiştir (Çizelge 2).

Çizelge 2: 616 kişinin faktörlere göre $\mathrm{X}^{2}$ sonuçları

\section{FAKTÖRLER}

\section{FAKTÖR 1 (Ambalai)}

Gıda alışverişinde ilk olarak etiket bilgilerini kontrol ederim.

Satın aldığım gıdanın son kullanma tarihini okurum.

Satın aldığım gıdanın içindekiler kısmını okurum.

Gıda alışverişi yaparken sağlıklı(besin değeri yüksek) olanları tercih ederim.

Gıda satın alırken, gıda ürününün üzerindeki kalite güvence işaretine dikkat ediyorum.

Gıda alışverişinde etikette gıda katkı maddelerini kontrol ederim.

FAKTÖR 2 (Katk1)

Sokakta satılan sütler, UHT sütlere göre daha sağlıklıdır.

Doğal ürünler daha sağlıklıdır teknolojik yolla üretilmiş gıdalar yeterince sağlıklı değil.

Kutu sütlerin içine bozulmalarını önlemek için zararlı katkı maddeleri koyuyorlar.

Pakette satilan Toz baharatlara güvenmiyorum, boya maddeleri katılmış olabilir.

Yoğurdumu evde yaparım, ambalajlı ürünlere güvenmem.

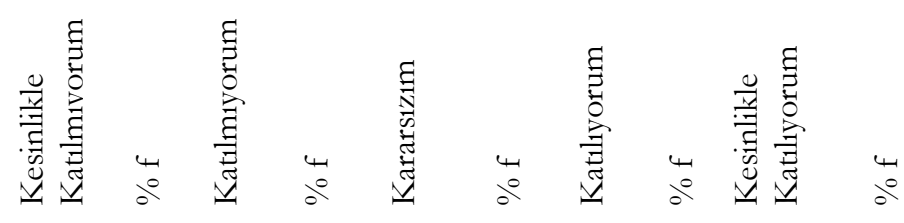

\begin{tabular}{|c|c|c|c|c|c|c|c|c|c|}
\hline 31 & 5 & 45 & 7.3 & 52 & 8. 4 & 276 & 44. 8 & 212 & 34.4 \\
\hline 22 & 3.6 & 16 & 2.6 & 27 & 4. 4 & 166 & 26.9 & 385 & 62.5 \\
\hline 36 & 5.8 & 54 & 8.8 & 103 & 16.7 & 247 & 40.1 & 176 & 28.6 \\
\hline 28 & 4. 5 & 68 & 11 & 129 & 20.9 & 240 & 39 & 151 & 2. 5 \\
\hline 42 & 6.8 & 93 & 15.1 & 123 & 20 & 213 & 34.6 & 145 & 23.5 \\
\hline 44 & 7.1 & 93 & 15.1 & 115 & 18.7 & 195 & 31.7 & 169 & 27.4 \\
\hline 150 & 24.4 & 162 & 26.3 & 175 & 28.4 & 92 & 14. 9 & 37 & 6 \\
\hline 51 & 8.3 & 77 & 12.5 & 87 & 14. 1 & 236 & 38.3 & 165 & 26.8 \\
\hline 103 & 16.7 & 75 & 12. 2 & 151 & 24. 5 & 162 & 26.3 & 125 & 20.3 \\
\hline 45 & 7.3 & 91 & 14.8 & 158 & 25.6 & 203 & 33 & 119 & 19.3 \\
\hline 70 & 11.4 & 141 & 22.9 & 130 & 21. 1 & 147 & 23.9 & 128 & 20.8 \\
\hline
\end{tabular}


Çizelge 2 devam

FAKTÖR 3 (Tavsiye)

Diyet kitapları olan bir doktor çikolata kanserojendir diye açıklama yaptı, doktor sonuçta bir bildiği vardır, çikolata tüketmem artık.

Son zamanlarda belirli gıdaların insan sağlığ1 üzerindeki etkileri konusunda yapilan açıklamalara göre tüketim alışkanlıklarım değişti.

Gazete veya dergilerde yeterli ve dengeli beslenmek üzerine yazılan yazıları özellikle okurum.

Tv de ki sağlıklı beslenme ile ilgili programları kaçırmam

Doktorlar bir şeyi yiyin ya da yemeyin derse dinlerim mutlaka.

Salam, sucuk gibi gıdaları tüketmem.

FAKTÖR 4 (Sağlık)

Bir doktor istediğiniz kadar kebap yiyebilirsiniz diyor, ne düşünürsünüz?

Çikolata kanser yapar.

Anne sütüyle zeytinyağı aynı şeydir.

Her gün 40 zeytin ye hastaneyi unut.

FAKTÖR 5 (Organik Pazarlar)

Organik Pazarlardan alışveriş yaparım.

Organik pazarlarda satılan gidalar daha sağliklidir.

Televizyon veya internette organik pazar yeri söylenirse özellikle organik pazarı tercih eder oradan alışveriş yaparım.

Organik pazarlar para tuzağıdır.

FAKTÖR 6 (Kimlik- Meslek)

Tv'de beslenme ile ilgili haberlerde açıklama yapan kişilerin mesleğine dikkat ederim.

Gıda mühendislerinin Tv'de açıklama yaptığını görmek istiyorum.

Beslenme ile ilgili bir açılama izlerken açıklamayı yapan kişinin kimliği önemlidir.

FAKTÖR 7 (Ün)

Televizyonda bir bitkinin zayıflattığ hakkinda haber izleyince ismini not eder ve alır denerim.

Tv'de reklamları yapılan zayıflama haplarına güvenir satın alırım.

Ünlülerin nasıl zayıfladığını merak eder ögrenince uygularım.

Ünlü yazarların diyet kitaplarını satın alırım.
258

20.5166

$26.9 \quad 176 \quad 28.6 \quad 49$

8

70

1

$\begin{array}{llllllllll}128 & 20.8 & 145 & 23.5 & 203 & 33 & 122 & 19.8 & 18 & 2 .\end{array}$

$\begin{array}{llllllllll}104 & 16.9 & 167 & 27.1 & 108 & 17.5 & 127 & 20.6 & 110 & 17.9\end{array}$

$\begin{array}{lllll}271 & 44 & 231 & 37.5 & 58\end{array}$

$229 \quad 37.2 \quad 204 \quad 33.1 \quad 147$

9.433

5. 423

3. 7

33

236

53. 6173

28. 185

23. 925

4. 111

1. 8

38. 3178

28. 9150

13. 820

3. 28

1. 3

88

$\begin{array}{llll}14.3 & 211 & 34.3 & 117\end{array}$

24. 4

6. $7 \quad 11$

1. 8

$\begin{array}{llll}6.3 & 106 & 17.2 \quad 205\end{array}$

19

16126.139

6.3

11

$\begin{array}{lllll}115 & 18.7 & 231 & 37.5 & 174\end{array}$

$\begin{array}{llll}33.3 & 199 & 32.3 & 67\end{array}$

10. 9

65

10. $6 \quad 153 \quad 24.8 \quad 240$

28. 2

2. 8

$\begin{array}{lllll}38 & 6.2 & 35 & 5.7 & 33\end{array}$

5. $4 \quad 250 \quad 40.6 \quad 260$

42. 2

$\begin{array}{llllllllll}32 & 5.2 & 19 & 3.1 & 71 & 11.5 & 222 & 36 & 272 & 44.2\end{array}$

$\begin{array}{llllllllll}33 & 5.4 & 36 & 5.8 & 48 & 7.8 & 234 & 38 & 265 & 43\end{array}$

$\begin{array}{llllllllll}294 & 47.7 & 196 & 31.8 & 66 & 10.7 & 45 & 7.3 & 15 & 2.4\end{array}$

$\begin{array}{llllllllll}510 & 82.8 & 81 & 13.1 & 12 & 1.9 & 8 & 1.3 & 5 & 0.8\end{array}$

$\begin{array}{llllllllll}385 & 62.5 & 146 & 23.7 & 50 & 8.1 & 27 & 4.4 & 8 & 1.3\end{array}$

$\begin{array}{llllllllll}296 & 48.1 & 220 & 35.7 & 58 & 9.4 & 32 & 5.2 & 10 & 1.6\end{array}$


Çizelge 2 devam

\begin{tabular}{|c|c|c|c|c|c|c|c|c|c|c|}
\hline $\begin{array}{l}\text { Gıda alışverişi yaparken lezzetli olan } \\
\text { gidalara yönelirim. }\end{array}$ & 30 & 4. 9 & 53 & 8.6 & 104 & 16. 9 & 320 & 51.9 & 109 & 17.7 \\
\hline Gıda alışverişi yaparken fiyat önemlidir. & 35 & 5.7 & 62 & 10.1 & 105 & 17 & 304 & 49.4 & 110 & 17. 9 \\
\hline Promosyon ürünler marka tercihimi etkiler. & 86 & 14 & 159 & 25.8 & 156 & 25.3 & 166 & 26. 9 & 49 & 8 \\
\hline \multicolumn{11}{|l|}{ FAKTÖR 9 (Doğal Gıda) } \\
\hline Margarin doğal bir gidadır. & 365 & 59.3 & 166 & 26.9 & 61 & 9.9 & 17 & 2.8 & 7 & 1. 1 \\
\hline Margarin tereyağı kadar besleyicidir. & 380 & 61.7 & 152 & 24.7 & 65 & 10.6 & 11 & 1.8 & 8 & 1.3 \\
\hline Gıdaların ışınlanması güvenlidir. & 162 & 26.3 & 127 & 20.6 & 244 & 39.6 & 57 & 9.3 & 26 & 4. 2 \\
\hline $\begin{array}{l}\text { Soda ile Maden suyu aynı şeydir, tatları da } \\
\text { etkileri de aynı sonuçta. }\end{array}$ & 263 & 42.7 & 176 & 28.6 & 123 & 20 & 34 & 5.5 & 20 & 3.2 \\
\hline \multicolumn{11}{|l|}{ FAKTÖR 10 (Yasak) } \\
\hline $\begin{array}{l}\text { Sağlıklı yaşamak için } 3 \text { beyaz olan tuz, şeker } \\
\text { ve undan uzak durmalıyı. }\end{array}$ & 55 & 8.9 & 97 & 15.7 & 112 & 18. 2 & 212 & 34.4 & 140 & 22.7 \\
\hline Şeker zehirdir. & 101 & 16. 4 & 163 & 26.5 & 163 & 26.5 & 119 & 19.3 & 70 & 11. 4 \\
\hline $\begin{array}{l}\text { Ekmek yememeliyiz. } \\
\text { Güvendiğiniz din alimleri Midye } \\
\text { tüketilmesinin haram olduğunu açılkladi. } \\
\text { Artık tüketmem o zaman. }\end{array}$ & 143 & 23.2 & 216 & 35.1 & 131 & 21.3 & 106 & 14. 4 & 129 & 20.9 \\
\hline \multicolumn{11}{|l|}{ FAKTÖR 11 (Hayvansal Gidalar) } \\
\hline $\begin{array}{l}\text { Sütü hayvandan geldiği gibi, kaynatmadan } \\
\text { içmek en sağllklı olanıdır. }\end{array}$ & 354 & 57.5 & 150 & 24.4 & 68 & 11 & 26 & 4. 2 & 18 & 2.9 \\
\hline $\begin{array}{l}\text { Yumurtayı hayvandan alır almaz çiğ olarak } \\
\text { içmek çok faydalıdır. Önemli olan } \\
\text { yumurtanın çatlamamış yani sağlam } \\
\text { olmasıdır. }\end{array}$ & 280 & 45.5 & 168 & 27.3 & 125 & 20.3 & 33 & 5.4 & 10 & 1.6 \\
\hline \multicolumn{11}{|l|}{ FAKTÖR 12 (Tazelik) } \\
\hline $\begin{array}{l}\text { Yemeğin tadı ve kokusu bozulmamışsa } \\
\text { zehirlemez, rahatlıkla tüketebilir. } \\
\text { Küflenmiş gıdaların küflü kısmı kesip }\end{array}$ & 201 & 32.6 & 165 & 26.8 & 129 & 20.9 & 98 & 15. 9 & 23 & 3.7 \\
\hline atılarak gerisi tüketilebilir. & 227 & 36.9 & 160 & 26 & 131 & 21.3 & 83 & 13.5 & 15 & 2.4 \\
\hline \multicolumn{11}{|l|}{$\underline{\text { FAKTÖR } 13 \text { (Reklam) }}$} \\
\hline $\begin{array}{l}\text { Televizyonda reklamı yapılan markalar } \\
\text { benim seçimimde önemlidir. }\end{array}$ & 122 & 19.8 & 199 & 32.3 & 147 & 23.9 & 137 & 22.2 & 11 & 1.8 \\
\hline $\begin{array}{l}\text { Reklamiarda oynayan kişiler mark } \\
\text { tercihimi etkiler. }\end{array}$ & 317 & 51.5 & 155 & 25.2 & 77 & 12.5 & 52 & 8.4 & 15 & 2.4 \\
\hline
\end{tabular}

\section{SONUÇ VE ÖNERİLER}

Bilinçli tüketici; örgütlü olan, bir mal ya da hizmeti satın alırken, ondan azami derecede yarar sağlamayı amaçlayan, gerçek gereksinimlerini göz önünde tutan, planlı ve belgeli alışveriş yapan, alışverişin nesnesi değil öznesi olduğunun bilincinde olan kişidir. Ayrıca kalitesi, standardı yüksek, sağlıklı, güvenli, çevreci ürünü seçme olgunluğunu taşıyan, tüm bunlarla birlikte bütçesine en uygun ürünü seçip tasarrufa önem veren kissidir. Aynı zamanda kaliteyi denetleyen, dolayssıyla, giderek ekonomiyi verimliliğe yöneltecek olan yadsınmaz bir sosyoekonomik unsurdur (Topuzoğlu ve ark., 2007). Gelişmekte 
olan ülkelerde, medyanın siyasi, ekonomik, teknolojik, mesleki unsurlardan bağımsız ve tarafsız olarak toplumun doğru ve anlaş1lır bilgiye erişimi, toplumun bu yöndeki bilincinin arttırlmasında daha etkin rol oynaması gerektiğ $i$ bilinen bir gerçektir. Risk iletişim kanalları web siteleri, basilı ve dijital yayınlar, toplantılar ve çalıştaylar, halk ile istişareler, ortak/paydaş ağları, sosyal ağlar, blog'lar vb. medya türleri olarak değerlendirilmektedir (Aytekin, 2015). İnsanların birçok konuda faydalandığı bu basın araçlarının, beslenmenin önemi ve gida maddelerinin tanıtımları konularında doğru ve sürekli bilgi vermeleri gerekmektedir (Yllmaz ve ark. 2007).

Yazılı, görsel ve sosyal medyanın tüketicinin gıda bilincini olumlu ve olumsuz etkilerinin bulunduğu gerek önceki yapılan çalışmalarda gerekse yapmış olduğumuz anket çalışmasında ortaya çıkmaktadır. Bilimsel verilere dayanmadan bazı şahsi yorumlamalardan tüketici etkilenerek beslenme konusunda endişeye kapılmakta, 'kanser yapar', 'zehirdir' gibi keskin cümlelerin tüketiciler üzerinde kafa karışıklığ yaşattığ1 görülmektedir. Ancak medya reyting gibi endişelerle bu can alıc1 açıklamaları ekranlara ve sosyal medyaya taşımaktadır. Bilimsel verilere bağlı olmadan bir gıdanın tek başına kanser yapması yerine, hastalıkların birçok etkene bağlı olduğu, bir gıdanın tam olarak etkisinin anlaşılabilmesi için belirli sayıda gruplara homojen olarak testlerinin yapılması ve sonuçlarının benzerliği baz alınarak ancak bilimsel olarak yorumlanabilmektedir. Besin etkileri insanların metabolizmasına, cinsiyetine, yaşına, boyuna, kilosuna, genetik yapısına, günlük harcadığı kalori miktarına dolayısıyla mesleğine, yaşadığı bölgedeki coğrafyada yetişen bitki örtüsüne ve yapılan hayvancilığa gibi daha uzatabilecek birçok etkene bağlıdır. Dolayısıyla her gida her insanın metabolizması gıdalara tam olarak aynı biyolojik tepkiyi veremeyecektir. Diyet listeleri oluşturulurken diyetisyenler kişiye özel besin tavsiyeleri listeleri oluşturmaktadır. Toplu ortak beslenme ancak yeterli ve dengeli beslenme tavsiyeleri ile her metabolizma için aynı olan besin öğeleri (Karbonhidrat, yağ, protein, vitamin, mineral, su) ile ortalama değerlere bağlı olarak yapilabilir.
Günümüzde yaşanılan gıda ile ilgili bilgi kirliliğinden dolayı tüketicinin kafasının karışıklı̆ıının bir nedeni de tüketiciye tavsiyede bulunan kişilerin ünlü olması, mesleği, kimliği gibi sebeplerden dolay1 etkilenmektedir. Bazı meslek gruplarından kişilerin özellikle medya tarafindan "doğru söyleyen insan", "yalanlarla mücadele eden bilim insanı" olarak tanıtılması tüketici tarafindan her söylenenin kanun olarak kabul edilmektedir. Doğru bilgi ancak doğru uzman kaynağ1 aracılığılla bilimsel verilere dayalı olarak verilebilir. Yazılı, görsel ve sosyal medya da bu sebepten dolayı gida ile ilgili yorumlarda mutlaka alanında uzman olan kişilere yer verilmelidir.

Gıda ile ilgili TV yayınları, internet kaynakları Gıda Tarım ve Hayvancılık bakanlığı tarafindan denetlenmelidir. Yine bakanlığa bağlı olan Alo174 Gıda hattında çalışanların halkın sorunlarına bilimsel ve güvenilir yanıtlar verebilmesi için Gıda Mühendisleri olmalıdır. Alanında uzmanlaşmış olan Gıda Mühendislerinin Gıda üretimi yapılan her alanda aktif bir şekilde çalıştırılması zorunlu bir hale getirilmeli ve denetlenmelerin daha sik yapılması sağlanmalıdır. Halkı Gıda ve beslenme konusunda bilinçlendirecek gerçek TV programları yapilmalı ve halkın gida konusunda sorusu olduğunda doğru kaynaklara yönlenebilmesi sağlanmalıdır. Halk Gıda Mühendisliği mesleğini daha iyi tanımalı ve Gıda Tarım bakanlığından onaylı olmayan hiçbir gıdayı satın almaması noktasında bilinçlendirilmelidir. 2015 yllından itibaren sosyal medyada bilgi kirliliğinin fazlalaşması ile önü alınamayan yanlış bilgilendirmelere karşı düzenlenmeye başlayan kongre ve sempozyumların sayıs arttırılarak oturumlar halka açık yapılmalı ve hatta canlı TV yayın ya da online internet yayınları ile desteklenmeli, halkın anlayabileceği sade bir dil ile doğru bilinen yanlışlara karşı bilinçlendirme çalışmaları sıklıkla yapılmalıdır. Beslenme ile ilgili yapılan TV yayınları RTÜK tarafindan incelenmeli halk sağlığını tehlikeye atacak yanlış bilgilendirmeler yapan bireyler, yayınlar veya kanallar caydırıcı cezalar ile cezalandirilmalı ve gerekirse yayından men edilmelidir.

"Gida bilinci" ilkokul, ortaokul, lise ve üniversitelere zorunlu seçmeli ders olarak 
okutulmalıdır. Her ilde bu eğitimi verecek gida mühendisleri görevlendirilmeli halkın küçüklükten itibaren okul öğrenimi süresince doğru dengeli ve yeterli beslenme konusunda bilinçlendirilmelidir.

\section{KAYNAKLAR}

Aytekin, N. D., (2015). A.B. Gida Güvenilirliğinde Risk İletişimi, Kamuoyunun Bilgilendirilmesi ve Türkiye'nin Durumu. AB Uzmanlık Lisans Tezi, T.C. Gida Tarım Ve Hayvancılık Bakanlığı, Ankara.

Artık N., (2014). Gıdada Bilgi Kirliliği Bilimsel Gerçekler Paneli. Http://Www.Ukon.Org.Tr/Duyurular/Pdf/Gid adabilgikirliligivebilimselgerceklerpanelibilginotu. Pdf

Avşar, T.A., Avşar, Y. K., Evrendilek, G.A. (2006). Gıda Güvenliği ve Başarılı Risk İletişimi: Medyanın (Yazilı, Sözlü, Görsel Basının) Sorumluluğu. Türkiye 9. Gıda Kongresi; 24-26 May1s 2006, Bolu, Ss. 11-14.

Halkman, A. K., (2015). Gıda Konusunda Yanlış Yönlendirmeler. Gazi Üniversitesi Öğretim Üyeleri Derneği, Akademik Bülten, Ss. 16-20.

Karaali, P. (2012). Gıda Güvenliği İçin Risk İletişim Stratejileri. 4. Gıda Güvenliği Kongresi, İstanbul.

Kocadaş, B. (2006). Kültür ve Medya International Journal Of Human Sciences, 1(1).

Newkirk, R. W., Bender, J. B., \&Hedberg, C. W. (2012). The Potential Capability Of Social Media As a Component Of Food Safety and Food Terrorism Surveillance Systems, Food borne Pathogens and Disease, 9(2), Ss. 120-124.
Songül, Y., (2015). Gidalarda Bilgi Kirliliği Ve Gıda Mühendisliği.https://www.Tarimdanhaber. .com/Haber/Gida/Gidada-Bilgi-Kirliligi-Ve-

Gida-Muhendisligi// (Erişim Tarihi: 13.06.2015)

Sungur, H. (2014). Gida Sektörünün Baş Edemediği Sorun: Bilgi Kirliliği. Ankara.

Solak, B. B.(2016). Televizyon Reklamlarında Ünlü Kullanımının Satın Alma Davranışı Üzerine Etkisi: Akdeniz Üniversitesi İletișim Fakültesi Öğrencilerine Yönelik Araştırma. Gümüşhane Üniversitesi, İletişim Fakültesi Elektronik Dergisi, Ss. 253-278.

Tezgüler S., (2016). Sosyal Medya Nedir? Http://Sosyalmedyakulubu.Com.Tr/Sosyalmedy a/Sosyal-Medya-Nedir.Html

Topuzoğlu, A., Hidıroğlu, S., Ay, P., Önsüz, F., \&İkisşık, H. (2007). Tüketicilerin Gıda Ürünleri İle İlgili Bilgi Düzeyleri Ve Sağlık Risklerine Karşı Tutumları. TSK Koruyucu Hekimlik Bülteni, 6(4), 253-258.

Türkel, F., (2016). Gıda Alg1sını Yönlendiren Gıda Dışı Etkiler. Gıda Hattı E-Dergi, Köşe Yaz1s1.Https://www.Gidahatti.Com/GidaAlgisini-Yonlendiren-Gida-Disi-Etkiler-6407/ (Erişim Tarihi: 26.06.2016)

Yamane, T.; (2001). Temel Örnekleme Yöntemleri. (İngilizceden Çeviren: Alptekin Esin, M. Akif Bakır Celal Aydın Ve Esen Gürbüzsel)., Literatür Yayıncillk, İstanbul, Ss.116-117.

Yilmaz İ., Uran H. (2007). G1da Maddeleri Tüketiminde Medyanın Rolü: Tekirdağ İli Örneği, ISSN: 1306-7648, G1da Teknolojileri Elektronik Dergisi, Ss.9-17. 